WellBeing International

WBI Studies Repository

$1-2013$

\title{
Science, Sentience, and Animal Welfare
}

Robert C. Jones

California State University, Chico, rcjones@mail.csuchico.edu

Follow this and additional works at: https://www.wellbeingintlstudiesrepository.org/ethawel

Part of the Animal Studies Commons, Ethics and Political Philosophy Commons, and the Nature and Society Relations Commons

\section{Recommended Citation}

Jones, R. C. (2013). Science, sentience, and animal welfare. Biology and Philosophy, 1-30.

This material is brought to you for free and open access by WellBeing International. It has been accepted for inclusion by an authorized administrator of the WBI Studies Repository. For more information, please contact wbisr-info@wellbeingintl.org.

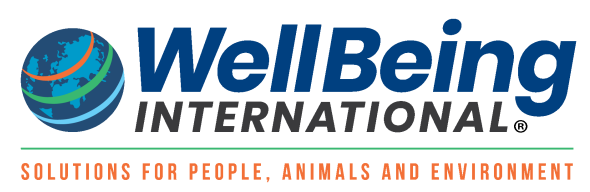




\title{
Science, Sentience, and Animal Welfare
}

Robert C. Jones

California State University, Chico

\section{KEYWORDS}

animal, welfare, ethics, pain, sentience, cognition, agriculture, speciesism, biomedical research

\begin{abstract}
I sketch briefly some of the more influential theories concerned with the moral status of nonhuman animals, highlighting their biological/physiological aspects. I then survey the most prominent empirical research on the physiological and cognitive capacities of nonhuman animals, focusing primarily on sentience, but looking also at a few other morally relevant capacities such as self-awareness, memory, and mindreading. Lastly, I discuss two examples of current animal welfare policy, namely, animals used in industrialized food production and in scientific research. I argue that even the most progressive current welfare policies lag behind, are ignorant of, or arbitrarily disregard the science on sentience and cognition.
\end{abstract}

\section{Introduction}

The contemporary connection between research on animal ${ }^{1}$ cognition and the moral status of animals goes back almost 40 years to the publication of two influential books: Donald Griffin's The Question of Animal Awareness: Evolutionary Continuity of Mental Experience (1976) and Peter Singer's groundbreaking Animal Liberation (1975). Since then, there has been a staggering amount of work exploring the scientific and ethical dimensions of animal physiology and cognition. Almost all theories concerned with the moral status of animals rely on scientific knowledge about the physiological and cognitive capacities of nonhuman animals.

With this background in mind, the topography of this paper is this:

I sketch briefly some influential contemporary moral theories concerned with the moral status of animals, highlighting the centrality of animal biology to each view. I then survey the data on animal cognition, focusing primarily on sentience, but looking also at a few other morally relevant capacities such as selfawareness, memory, and mindreading (i.e., theory of mind). Lastly, I discuss two examples of current animal welfare policy: animals used in industrialized food production and in scientific research. I argue that even the most progressive current welfare policies lag behind, are ignorant of, or arbitrarily disregard the science on sentience and cognition. 


\section{The bases of moral considerability}

Traditionally, Western ethical theory and practice have taken as an assumption the belief that only humans are the proper subjects of moral concern, occupying a separate and superior moral sphere from that of animals. Implicit in this view, known as human exceptionalism, are two distinct claims. ${ }^{2}$ First is the claim that humans are unique in their possession of some capacity (or set of capacities) within the physiological, cognitive, emotional, social, etc., domains; second is the claim that the possession of such capacities is what makes humans morally superior to those who lack such capacities. The first claim is largely empirical, the second, normative. Further, these two claims represent two fronts on which philosophers and animal welfare advocates have begun to dismantle the foundations of human exceptionalism.

Over the last 40 years, the central strategy employed by philosophers seeking to undermine human exceptionalism and increase the moral status of animals has been to identify some set of capacities, central to a particular moral theory, that bestows upon the possessor intrinsic moral worth. Quite a number of candidate capacities have been proposed by various philosophers.

Peter Singer (1975) argues that sentience (i.e., the capacity for pain and suffering) is a prerequisite for having interests and, in fact, is "the only defensible boundary of concern for the interests of others" (1975: 9).

Tom Regan (1983) argues that the capacity to be the subject of experiences that matter to that individual, i.e., to be a "subject-of-a-life," is what matters morally. For Regan, individuals are subjects-of-a-life if they possess

beliefs and desires; perception, memory, and a sense of the future, including their own future; an emotional life together with feelings of pleasure and pain; preference and welfare-interests; the ability to initiate action in pursuit of their desires and goals; a psychophysical identity over time; and an individual welfare in the sense that their experiential life fares well or ill for them, logically independent of their being the object of anyone else's interests (1983: 243).

Bernard Rollin (1981) argues that animals' neurophysiological, ethological, biochemical, behavioral, and phenotypic characteristics, capacities, and traits-an animal's species-typical behaviors (i.e., its telos)must be allowed to be expressed if the interests of the individual are to be respected, and that precisely what each animal's interests are is to be determined empirically.

Thus, the strategy for those philosophers seeking to expand the moral status of animals has been to question the existence of a clear distinction between all humans and all animals with regard to the possession of certain morally relevant capacities. These candidate capacities-sentience, selfawareness, memory, and mindreading - though not the only capacities that might bear on the moral status of individuals, represent a solid starting place. Since the first claim that undergirds human exceptionalism, the claim that humans are unique in their possession of some set of morally relevant capacities, is primarily an empirical one, it is quite useful-and in some cases, indispensable - to see what science has to say about just which animals possess which capacities.

Though these capacities and properties are crucial in determining which things among the furniture of the universe are the proper objects of moral concern, some caution is in order. Since our epistemic access to the mental lives of animals is even more limited than access to each other's minds, we must be cautious about cognitive attributions, and selective about the kinds of evidence for such attributions we have at our disposal. 
As Rogers and Kaplan (2004) argue, basing the moral status of animals on comparative cognition and other biological measures can be fraught. Take, for example, the well-known mirror self-recognition (MSR) test (Gallup 1970). (More about that later.) Self-awareness as measured in these kinds of tasks is limited to the visual modality, failing to take into account other modalities of self-representation (e.g., auditory, tactile, and olfactory) as well as certain salient anatomical differences (Rogers and Kaplan 2004: 176-177).

Moreover, only a small fraction of the almost 6,000 extant mammalian species, 10,000 avian species, tens-of-thousands of reptile and amphibian species, a still greater number of fish species, and millions of insects and spiders have been investigated for things like sentience and cognitive abilities.

Further and related to this worry is the narrow sense in which claims of folk psychology (and, indeed, folk psychology itself) are characterized. For example, the accepted methodological paradigm in animal cognition research characterizes folk psychology as necessarily involving conspecific belief attribution and seeks only evidence of the kinds of behaviors that confirm and conform to this model of psychology. However, Kristen Andrews argues forcefully that the standard account of folk psychology demands more than is necessary, since the standard account assumes that correct prediction of a conspecific's behavior requires the ability to attribute beliefs, false beliefs, and beliefs differing from one's own. Andrews rejects belief attribution as a necessary condition for conspecific behavior-prediction, urging researchers to integrate social psychology research ${ }^{3}$ on how normal adult humans actually predict behavior (Andrews 2012).

Despite these challenges, comparative biological methods remain the most reliable metric in our understanding of the mental lives of animals and those properties that bear on questions of animal welfare. $^{4}$

\section{Sentience: pain and suffering}

A solid methodological framework for an investigation into whether an animal is sentient includes investigating whether a particular organism possesses or exhibits

A central nervous system and other structures and psychoactive chemicals homologous to those known to control pain response in humans (e.g., neuroanatomical (opioid receptors, nociceptors)) and neurochemical (opioids (such as endorphins and encephalins) ${ }^{5}$ ).

Physiological or behavioral response to noxious ${ }^{6}$ (or positive) stimuli, analgesics, and anesthetics. ${ }^{7}$

Though these properties and capacities may, at first glance, seem to provide a clear framework for investigation, some difficulties quickly arise. Pain is a notoriously difficult phenomenon to understand, not only in ourselves but especially in nonhuman animals. ${ }^{8}$ Data on pain present at least two challenges. ${ }^{9}$ The first is that data on the high variability between the physiological mechanisms and the phenomenal aspects of pain are often confounding, raising puzzles about the connection between the two. For example, the very same kind of stimuli can elicit a pain response of widely varying intensity (or none) in different individuals or even in the same individual at different times, making generalizations from humans to animals even more challenging. Though we have a good idea of how the nervous system detects and responds to painful events in humans, exactly how the human brain processes the stimuli and generates the phenomenal aspects of pain induced by injury remains far less clear.

A second challenge presented by the data on the connection between the physiological mechanisms and the phenomenal aspects of pain are abnormalities such as congenital analgesia or, even more puzzling, 
pain asymbolia, a type of dissociation affect involving pain without painfulness. In these bizarre, almost inconceivable cases, a subject feels pain but is not in pain. ${ }^{10}$

Given these challenges, how might our investigations into the question of animal pain reliably proceed? Common sense suggests that at least mammals and birds are sentient. But what about reptiles? Amphibians? Fish? Invertebrates? Do lobsters feel pain when boiled alive? Scallops, when shucked? Cockroaches, when blast with insecticide? Here, intuitions begin to break down, and so it seems only science can step in where commonsense intuitions begin to falter. ${ }^{11}$

\section{What is pain?}

The International Association for the Study of Pain (IASP) (1994/2011) provides what seems at first blush to be a reasonable definition of pain as "an unpleasant sensory and emotional experience associated with actual or potential tissue damage, or described in terms of such damage" (209). The IASP definition is followed by a footnote informing us that "pain is always subjective" and that the IASP definition intentionally "avoids tying pain to the stimulus" (209). However, the IASP definition of pain is both physiologically and philosophically problematic since it (a) emphasizes subjective experience and selfreport while supporting conflicting philosophical interpretations of pain (e.g., subjectivist and objectivist views of pain), and (b) remains silent on the question of the relationship of the physiological bases of pain to its phenomenal aspects (Allen 2010).

Yet, given that pain and suffering are likely very old phenomena, it would be strange were pain not widespread across varied species, did not provide selective advantage, nor serve a similar adaptive function as it does in humans. Consequently, an understanding of the basic mechanics of pain is imperative to understanding its role in animal sentience.

\section{The mechanics of pain}

Pain in humans is at least a two-step process. The first step involves the stimulation of special receptors called nociceptors that transmit injury detecting electrical impulses to the spinal cord, triggering an automatic reflex response. At this first stage, there are no conscious, phenomenal aspects of the experience. In the second stage, the signal then moves from the spinal cord to the neocortex at which point the phenomenal aspects of pain kick in and we experience the unpleasant sensation associated with tissue damage. Though researchers are clear about the mechanisms involved in the first stage, it is the second stage of the process-the conscious detection of pain-that remains somewhat of a mystery.

In addressing the issue of animal pain, we can start with the questions, "Which animal groups possess nociceptors (or exhibit a "nociceptive response")?', and 'Do they (and if so, how do they) respond to noxious stimuli, analgesics, and anesthetics?' We can further explore which organisms possess neural organs more complex than simple neural nets (e.g., organs such as ganglia, brain masses, or brains), and of these, which possess nociceptor-to-brain pathways.

Vertebrate pain: fish, amphibians, and reptiles

Despite a handful of skeptics, ${ }^{12}$ most researchers and philosophers writing on the subject believe that all vertebrates are sentient. However, with regard to fish pain, skepticism has persisted even among those ready to attribute pain sensation to other, "higher" vertebrates. ${ }^{13}$ Popular interest in the question of fish pain and welfare has increased in recent years. For example, 2009 saw a number of articles in the popular media on fish pain and welfare, ${ }^{14}$ while 2010 saw both the publication of a popular-press book on the topic and an entire conference dedicated to issues of fish welfare, science, and ethics. ${ }^{15}$ This explosion of interest in the issue of fish welfare can be traced back to the publication of two papers. 
In the first, Sneddon et al. (2003a) made three important findings, namely, that (a) fish possess nociceptors capable of detecting noxious stimuli, (b) nociceptor-to-fish-brain pathways process nociception signals in a quite similar way as that of the "higher" vertebrates (including humans), and (c) fish behavior is adversely affected by the administration of noxious stimuli. After confirming the existence of nociceptors and electrophysiological pathways requisite for the transmission of pain signals, experimenters injected noxious chemical stimuli (bee venom and vinegar) into the lips of rainbow trout. The results demonstrated that the noxious chemicals affected both the physiology (increased breathing rate) and the behavior (decreased appetite) of the trout, responses consistent with pain reactions and behaviors in more-complex vertebrates.

In the second prominent paper on fish pain published that same year, Sneddon (2003) found that the administration of morphine to the lips of rainbow trout injected with noxious stimuli significantly reduced pain-related physiological and behavioral responses. Sneddon concluded that if morphine acts as an analgesic in the rainbow trout, then such pain-related behaviors are not simply reflexes but are rather indictors of pain perception in fish. Anglers discomforted by these results found little relief in subsequent studies and meta-analyses that only further confirmed these findings (Chandroo et al. 2004; Sneddon 2007; Braithwaite and Boulcott 2008; Nordgreen et al. 2009; Brown et al. 2011).

In another study, Sneddon et al. (2003b) observed that noxiously stimulated rainbow trout no longer displayed classic fear-response behavior when presented with a novel object (Lego blocks). Whereas control trout spent most of their time moving away from the novel object, noxiously stimulated trout spent most of their time in close proximity to the novel object and showed no additional increase in respiration rate to novel-object presentation. The researchers concluded that the noxious treatment commanded the majority of the attention capacity in the fish subjects, evidence that the trout were experiencing some level of pain.

\section{$\underline{\text { Invertebrates }}$}

Insects and spiders

The literature on insect and arachnid pain is astonishingly impoverished. For over 30 years, the established view (Wigglesworth 1980) was that insects by in large do not feel pain. Yet, Wigglesworth goes on to argue that certain insect behaviors (e.g., escape behavior when presented with noxious stimuli) indicate that some insects must experience some form of pain. Eisemann et al. (1984) concluded that the evidence "does not appear to support the occurrence in insects of a pain state" (167) ${ }^{16}$ However, Tracey et al. (2003) and Tobin and Bargmann (2004) have discovered nociception in at least some insects, namely, Drosophilia. Neely et al. (2011) found nociception in response to thermal noxious stimuli as well as what the researchers refer to as a "pain" gene in Drosophilia. Other evidence of insect pain includes evidence of opioid receptors in crickets (Dyakonova et al. 1999) and nociception (or, at least, a nociceptive response) in moth larvae (Walters et al. 2001). In their work on spider pain, Eisner and Camazine (1983) found that "[t]he sensing mechanism by which spiders detect injected harmful chemicals such as venoms. . may be fundamentally similar to the one in humans that is coupled with the perception of pain" (3382).

\section{Crustaceans}

The question of crustacean pain-particularly the question, 'Do lobsters feel pain?'-is one that interests not only philosophers and scientists, but also the general public. ${ }^{17}$ Physiologically, crustaceans possess nociceptors, ganglia, and nociceptor-to-ganglia pathways (Ross and Ross 2008). Though crustacean pain attribution is not yet widely accepted, findings are beginning to support crustacean sentience. Barr et al. 
(2008) demonstrated that when the antennae of prawns were exposed to noxious chemical stimuli, the crustaceans responded with increased grooming of the antennae, yet when an anesthetic was applied, the grooming behavior subsided. Elwood and Appel (2009) found that the more intensely hermit crabs are electrically shocked, the more willing they are to abandon their shells for new shells, while Lozada et al. (1988) showed that injections of analgesic and opioid receptor antagonists into male crabs reduced response to electric shock. Dyakonova (2001) concludes that "[a]lready in higher invertebrates. . . many functions of opioids. . . are similar to those in vertebrates" suggesting that "the main events in formation of functions of the endogenous opioid system have occurred in the lower invertebrates" (335). Barr et al. (2008) conclude that such findings are "consistent with the idea that these crustaceans can experience pain" (745).

Annelids, nematodes, and mollusks

Though proto-nociception is found in jellyfish and sea anemones, full-blown nociceptors are found in a wide range of bilateria such as annelids, nematodes, and mollusks (Ross and Ross 2008; Smith and Lewin 2009). Both marine and terrestrial worms (annelids) are found to possess not only nociceptors but a ganglion and nociceptor-to-ganglia pathways (Ross and Ross 2008). Behaviorally, worms react to noxious stimuli. Anatomically, some terrestrial snails and earthworms are found to produce endorphins and encephalins (Dalton and Widdowson 1989; Kavaliers and Ossenkopp 1991; Ross and Ross 2008). Further, since the administration of opioidal substances has been shown to produce analgesic effects, it is believed that such (and similar) annelids must possess opioid receptors as well (Ross and Ross 2008; Smith and Lewin 2009).

As regards mollusks, it's important for our purposes to separate bivalves (clams, scallops, oysters, etc.) from cephalopods (octopuses, squid, and cuttlefish). Though bivalves have quite a simple nervous system, there is some evidence that some mollusks such as snails may be sentient. For example, placement of a land snail on a hotplate results in the snail's lifting of the anterior portion of the extended foot. However, when opiate agonists are introduced, "increased withdrawal latency" is observed (Smith and Lewin 2009). In testing anesthetics in oysters, Culloty and Mulcahy (1992) noted that magnesium chloride induced "anesthesia quickly, allowing rapid recovery with minimal stress and mortality" (249). Though consensus opinion holds that since bivalves lack a sufficiently complex nervous system they are probably not sentient, it appears that the jury is still out on the matter.

Cephalopod mollusks (octopuses, squid, and cuttlefish) on the other hand, have highly developed brains. Findings indicate that these cephalopods possess a central nervous system that rivals in complexity that of the phylogenetically distant vertebrates (e.g., mouse and human) (Wollesen et al. 2009), and that a convergent evolutionary process has led to the selection of vertebrate-like neural organization and "activity-dependent long-term synaptic plasticity" (Hochner et al. 2006: 308). Behaviorally speaking, cephalopods exhibit quite a range of advanced behaviors and are almost certainly sentient (Ross and Ross 2008).

\section{Jellyfish and sea anemones}

Although "nociceptive responses" appear to exist in jellyfish and sea anemones (Cnidaria) and comb jellies (Ctenophora), the Cnidarian nervous system is merely a "nerve net" and not robust enough to count as a full-blown nervous system (Smith and Lewin 2009). Noxious stimuli will induce in some Cnidaria the "closure reflex," a nociceptive response. Yet, since the nervous systems of such aquatic invertebrates take the form of such neural nets-nothing remotely as sophisticated as the central nervous systems of some invertebrates (and all vertebrates)—skepticism concerning pain in organisms such as jellyfish seems warranted. In fact, since the neocortex appears to play a central role in human pain, Rose 
(2002) goes so far as to claim that any species lacking this structure will be incapable of feeling pain. However, this view is not widely shared (Sneddon 2007; Ross and Ross 2008). Further, other indicators of pain capacity beyond homologous biological structures (e.g., the possession of opioid receptors and producers) must also be considered.

\section{Psychological suffering in animals}

Evidence suggests that some animals suffer psychological pain in the form of fear and stress. ${ }^{18}$ In humans, the stress response triggers a number of physiological responses including the release of cortisol and other glucocorticoids, hormones correlated with increased stress levels. Research has found that dominance hierarchies in social species such as apes, Old World and New World monkeys, and other vertebrates such as rodents and birds show a relationship between social status and measures of stress physiology such as increased cortisol and other glucocorticoid levels (Abbott et al. 2003; Sapolsky 2005).

Setchell et al. (2010) found that the relationship between dominance rank and glucocorticoid levels in male baboons changed direction according to the stability of the dominance hierarchy such that glucocorticoid levels were higher in subordinate males under stable conditions, but under conditions of instability, higher-ranking males had higher glucocorticoid levels. Further, males with higher cortisol levels suffered an increased rate of gastrointestinal parasite infection, evidence that glucocorticoids may suppress the immune system in species other than humans. Cheney and Seyfarth (2007) found that female baboons suffer elevated cortisol levels following the death of a close relative and when nursing in the presence of threatening male, while Ashley (2007) measured increased cortisol levels in rainbow trout kept in extreme confinement conditions.

In a meta-study of various physiological responses to anthropogenic noise as a stressor in animals (including marine mammals), Wright et al. (2007) conclude that anthropogenic noise can result in a range of interwoven stressors including anxiety and loss of foraging opportunities. The authors recommend that scientists and animal caregivers take such stressors into consideration when planning research or when assessing the environmental impact of noise on animal inhabitants.

Studies also demonstrate that captive chimpanzees suffer from a variety of serious stress- and depression-associated behavioral abnormalities. Birkett and Newton-Fisher (2011) found that of 40 socially-housed zoo-living chimpanzees from six independent groups in the US and UK, abnormal behaviors (including self-mutilation, repetitive rocking, and consumption of feces) were present in all sampled individuals, despite differences between groups in size, composition, and housing. Birkett and Newton-Fisher conclude that, while most behavior of zoo-living chimpanzees is "normal" in that it is typical of their wild counterparts, abnormal behavior in captive chimpanzees is endemic despite enrichment efforts. The authors suggest that there is an urgent need to "understand how the chimpanzee mind copes with captivity, an issue with both scientific and welfare implications that will impact potential discussions concerning whether such species should be kept in captivity at all" (6).

Ferdowsian et al. (2011) report an association between traumatic events (e.g., maternal separation, social isolation, or experimentation) and the emergence of behavioral disturbances resembling depression and posttraumatic stress disorder (PTSD) in captive chimpanzees. Using behaviorally anchored DSM-IV criteria for PTSD and major depression, the researchers found that $58 \%$ of chimpanzees with prior histories of experimentation, orphanage, illegal seizure, or violent human conflict exhibited depression-associated behavior (compared with $3 \%$ of chimpanzees in the wild), while $44 \%$ of such chimpanzees exhibited PTSD (compared with $0.5 \%$ of chimpanzees in the wild). The authors conclude that the findings underscore the "association between psychopathology and conditions that 
include captivity, confinement, physical harm, loss of social bonds, and isolation" (10) and the "importance of ethical considerations regarding the use of chimpanzees in experimentation and other captive settings" (6).

Bradshaw (2009) and Bradshaw et al. (2005) report that elephants-both in captivity and in the wild where elephants have experienced mass deaths and social breakdown from poaching, culls, and habitat loss-display symptoms associated with human PTSD such as abnormal startle response, depression, unpredictable asocial behavior and hyperaggression. And Chandroo et al. (2004) and Yue et al. (2004) report evidence of psychological suffering in the forms of fear and stress in rainbow trout when in the presence of frightening stimuli.

\section{Some tentative conclusions regarding animal pain and suffering}

This survey demonstrates the wide range of animals that can respond to tissue damage or injury with nociception or nociceptive-like responses as well as the number of species who possess the capacity to suffer psychologically. Given the complexity of the phenomenon of pain-that it requires not only nociception but neural complexity, perception, and some level of phenomenal consciousnessconclusions regarding invertebrate pain would be premature. However, considering the growing body of physiological and behavioral evidence, when it comes to issues of welfare it is probably best to employ the precautionary principle regarding our treatment of many invertebrates.

Regarding pain in some vertebrates, though the usual epistemological challenges arise whenever we encounter proclamations about the mental states of other beings (especially with creatures like reptiles, amphibians, and fish), the most sensible approach to issues of vertebrate pain and welfare remains, once again, the precautionary principle. ${ }^{19}$

\section{Higher cognition and animal welfare}

As mentioned above, philosophers seeking to expand the moral status of animals are interested not only in sentience as a morally relevant property, but the "higher" cognitive capacities as well. Cognitive capacities such as self-awareness, beliefs, desires, memory, belief- and desire-attribution to conspecifics, and psychophysical identity over time are central to many of the philosophers' views discussed. Thus, it is useful to investigate what science has to say regarding these capacities. ${ }^{20}$ However, as we saw with the question of animal pain and suffering, epistemological challenges and unnecessary anthropomorphism ${ }^{21}$ caution against too hastily drawing unwarranted conclusions regarding the cognitive capacities of nonhuman animals.

\section{Self-awareness}

An organism's ability to recognize or conceptualize an independent self plays a key role in a number of theories concerned with the moral status of animals. Self-awareness allows a being to reflect on the contents of his own consciousness, something it is believed only humans can do robustly. This kind of awareness, this reflective consciousness, seems at least necessary for "higher" cognitive capacities such as understanding, examining, evaluating, and remembering one's own and others' experiences and actions. It is exactly these kinds of second-order mental capacities that some philosophers (e.g., Kant) claim make us (and only us) moral beings.

Since 1970, the standard measure of self-awareness has been mirror self-recognition (MSR) ${ }^{22}$ (Gallup 1970, Gallup et al. 2002). As an indicator of self-awareness, the MSR test is supposed to demonstrate whether subjects can recognize themselves in a mirror. There are a couple of ways researchers assess an animal's response to seeing her image in a mirror. In the classic MSR task, experimenters see how the 
animal reacts to seeing a mark (typically a small dot of rouge) placed on her forehead (or other part of her body) not readily visible to herself. If the animal touches the spot on her own body rather than the image of the spot in the mirror, it is claimed that the animal is aware that the image is of herself. A second method is to note whether the subject uses the mirror to examine parts of her body that she cannot see otherwise, for example, touching or examining her eyes or teeth. The significance of the results of this kind of task are such that if an animal recognizes her image in a mirror as an image of herself (and not, for example, a conspecific), then it is claimed that the animal is self-aware. MSR is seen as such an important criterion of self-awareness, that some animal advocates propose it as a criterion for personhood (Wise 2002). Before looking at the data however, it should be noted that explanations for MSR failure-other than a lack of self-awareness—are numerous and significant.

Schilhab (2004) and others provide important methodological and interpretive critiques of MSR as a measure-especially as the measure-of self-awareness. Schilhab points out that MSR is highly dependent on visual capability such that even simple deficiencies in eyesight could account for MSR failure. Even if species have comparable visual capacities, it does not follow that they attend similarly to marks placed upon their bodies.

As discussed earlier, Rogers and Kaplan (2004) note that MSR fails to take into account other, non-visual modalities of self-representation. Dogs, for example, pay less attention to how other dogs look but are attentive to how they and others smell. ${ }^{23}$ Further, MSR tasks can be administered only on captive animals who may not be representative of their species.

In addition to these methodological worries, questions regarding the interpretation of MSR results provoke further criticism. Schilhab (2004) notes that anthropocentric assumptions inherent in MSR favor organisms constitutionally comparable to humans, assumptions that may lead to erroneous conclusions, e.g., claims supporting a supposed cognitive gap between the great apes (including humans) and the rest of the animal kingdom. Schilhab further argues that MSR ignores important social aspects of selfawareness, significant given that recent investigations in primates suggest that what individuals know about the visual experience of other individuals indicates insight into social problems (e.g., Hare et al. 2000).

Asendorpf et al. (1996) argue that the classic MSR task assumes that recognition of the dot of rouge must lead to a recognition that (a) it is not a "normal" marking, and that (b) the subject should get rid of it. However, the researchers found that MSR produced false negatives in children when the child's recognition of the dot did not lead her to try and remove it. More generally, their criticism of the MSR task is that there may be quite a number of alternative reasons for any non-interaction with the dot other than lack of self-awareness.

Though these difficulties caution against lending MSR too central a role in measures of self-awareness in nonhuman animals, it remains worthwhile to examine the literature on animal MSR. ${ }^{24}$

\section{Great apes}

While it is well-established that both the common chimpanzee and bonobo exhibit MSR (Gallup 1970; Povinelli et al. 1993; de Veer et al. 2003; Walraven et al. 1995), the presence of this capacity in gorillas remains contested (Shumaker and Swartz 2002). While Koko (a gorilla proficient in sign language) has demonstrated that she recognizes herself in the mirror, most gorillas have failed the MSR task. The most common explanation of these results is gorillas' aversion to direct eye contact (Patterson and Cohn 1994). However, Posada and Colell (2007) found that Xebo-a 17-year-old male gorilla habituated both 
to observers and to a mirror-exhibited no aversion to eye contact and clearly exhibited a positive response to the mark test.

\section{Other primates}

Though it has been long-believed that primates such as monkeys lack MSR, findings seem now to support claims that some primates other than great apes pass the mirror test (Anderson and Gallup 2011). For example, de Waal et al. (2005) found that capuchin monkeys recognize their reflections in a mirror as special, and not merely an image of a conspecific.

Though macaque monkeys have long-failed the mark test, Rajala et al. (2010) observed self-directed behaviors in rhesus macaque lab monkeys. When presented with a mirror, the macaques exhibited extensive observation and grooming of their head implants and genital areas, parts of their bodies that cannot be readily and directly observed without the help of a mirror. In some cases, the monkeys even turned themselves upside down or adjusted the mirror to get a better view of themselves. These behaviors ceased once the mirror was covered or removed.

Couchman (2012) claims that rhesus monkeys appear to have a sense of self-awareness previously not attributed to such primates. In the study, rhesus monkeys were able to differentiate a computer cursor that they controlled with a joystick from an array of cursors on the screen controlled by others, suggesting that the primates possess a kind of "self-agency."

\section{Dolphins and other animals}

Other animals who exhibit MSR in one form or another include Asian elephants (Plotnik et al. 2006), killer whales (Delfour and Marten 2001), and even magpies (Prior et al. 2008). Though pigs lack MSR, Broom et al. (2009) found that pigs can utilize information obtained from a mirror.

Bottlenose dolphins have clearly demonstrated MSR. In the most conclusive study, Reiss and Marino (2001) report dolphin subjects watching their reflections while performing head movements and body postures in front of a mirror. They also used the mirror to examine the insides of their mouths, and even engaged in sexual behavior much more often when in front of the mirror. Upon being marked for the first and only time on the tongue, one dolphin engaged in a mouth opening-and-closing sequence never before observed. At no time did any of the dolphins behave towards the reflection as though it were a conspecific (White 2007).

Other studies further support the notion that dolphins are self-aware. For example, there is evidence that each dolphin possesses a unique "signature whistle," a kind of dolphin "name" that remains the same throughout a dolphin's lifetime and whose primary function is to communicate to other dolphins the dolphin's identity. Such signature whistles appear further to function as contact calls between individuals (e.g., mothers and their calves) separated by great distances. Even more intriguing is the observation of some dolphins mimicking the signature whistle of another dolphin in an apparent effort to get his or her attention (Janik et al. 2006; White 2007).

As noted earlier, comparative cognition and other biological measures can be a dodgy endeavor. Yet, despite these challenges, it is safe to infer that species other than humans possess at least some rudimentary form of self-awareness, one that is perhaps not as robust as that of human persons, but selfaware nonetheless. 
Imitation

Metrics other than MSR also provide evidence of self-awareness in animals. Imitation, for example, involves copying the form of a particular behavior. In genuine imitation, one's intention to copy implies some kind of self-representation (DeGrazia 2009). Further, imitation plays a role in prosocial behaviors. For example, during social interactions, humans often unintentionally imitate the behaviors of others, increasing rapport and empathy between interaction partners.

Horner and Whiten (2005) found that young wild-born chimpanzees from an African sanctuary employed imitation strategies when observing a human demonstrator use a tool to retrieve a reward from a puzzlebox. Paukner et al. (2009) report that capuchin monkeys differentiate and prefer an experimenter imitating them to an experimenter performing non-imitative contingent actions. The monkeys looked longer at, spent more time in proximity to, and choose to interact more frequently with imitators over non-imitators.

\section{Memory}

Though memory can be characterized simply as the encoding, storage, and retrieval of information, memory as a component of rationality is classified by function into a number of different memory types. ${ }^{25}$ Of the various types of memory, episodic memory seems the most relevant to animal welfare. Episodic memory involves the conscious recollection of unique personal experiences as well as the ability to mentally project oneself into the future (Tulving 1985; Turving 2005; Crystal 2009). Episodic memory in humans is believed to require three things: (a) a concept of the self, (b) autonoetic awareness, and (c) chronesthesia, i.e., the ability to subjectively sense the objects, location, and time of particular events (i.e., the "what," "where," and "when" of particular events). Autonoetic awareness involves awareness of the self as the subject of the remembered (or forwardly projected) experience. Autonoetic awareness works in conjunction with autonoetic consciousness, which emerges through the retrieval of a memory of a personally experienced event and is identified with the phenomenal aspects of the remembered eventthe what-it-was-like-ness of the remembered event. Episodic memory in humans involves the capacity to mentally represent and become aware of subjective experiences. As we have seen, self-awareness of this sort has implications for animals' moral standing. But since evidence of conscious recollection of personal experience is (at least in humans) reported linguistically, it is difficult (if not, as some claim, impossible (Tulving 1985)) to assess whether nonhuman animals exercise episodic memory. Due to this linguistic barrier and since only the behavioral aspects of episodic memory can be observed in nonhuman animals, researchers refer to episodic memory in nonhumans as episodic-like memory.

In a landmark study of episodic-like memory in nonhuman animals, Clayton et al. (1998) produced evidence that Western scrub jays possess the ability to remember the location, time, and identity of various food items they cached. In the study, scrub jays cached peanuts in soil on one side of a spatially distinct area, and waxworms in another. The birds were then removed from the cache area. Four hours later they were permitted back into the cache area to retrieve some of the food items and re-cache. Following this second caching event, the birds were removed from the area for $120 \mathrm{~h}$. Within as few as four trials, scrub jays learned that the worms that had been cached $124 \mathrm{~h}$ before had rotted, whereas $4 \mathrm{~h}$ after caching, the worms remained fresh. Salwiczek et al. (2010) further demonstrated that scrub jays' memory for their caches incorporated flexibility when researchers used food stuffs of different rates of decay.

Adapting the paradigms of Salwiczek et al., Martin-Ordas et al. (2010) demonstrated episodic-like memory in chimpanzees, orangutans, and bonobos. Apes chose perishable food significantly more after 5 min and non-perishable food after $1 \mathrm{~h}$, demonstrating that apes remember in an integrated fashion the "what," "where," and "when" of an event. In other words, the apes were able to distinguish between 
different events in which the same food items were hidden in different places at different times, hallmarks of episodic memory.

Similar results have been obtained in a study of hummingbirds (Henderson et al. 2006), and studies involving rodents demonstrated that rats and mice exhibit episodic-like memory in their capacity for detailed representations of remembered events (Eacott et al 2005; Babb and Crystal 2006; Dere et al. 2006; Crystal 2009). Basile and Hampton (2011) report that rhesus monkeys demonstrate episodic-like memory in their ability to recall shapes from memory and reproduce them on a touchscreen with great flexibility. There is even some evidence of episodic-like memory in bees (Pahl et al 2007).

Abeyesinghe et al. (2005) found evidence not only of episodic memory in the common domestic chicken, but also that hens demonstrate delayed gratification, self-control, and the ability to anticipate the future, all associated with the capacity for pre-emptive anxiety and the generation and frustration of expectations.

It is thus reasonable to conclude that a variety of species possess the capacity to encode past events in ways functionally similar to robust episodic memory. However, given that the subjective, phenomenal aspects of memory (the autonoetic aspects)—reported linguistically_are crucial to the robust concept of episodic memory, researchers face a serious challenge in countenancing such an essential component of episodic memory in nonhuman animals.

\section{Mindreading}

Dennett (1976) argues that of the various capacities and abilities that constitute personhood, the most central is the ability to attribute mental states to oneself and to others, i.e., to have a theory of mind (or to be capable of mindreading). This is because the ability to mindread is necessary for things like selfawareness, moral autonomy, and empathy. Some argue that any being that can mindread is (or should at least be legally recognized as) a person (Mitchell 1994). Though investigations into mindreading in animals are scientifically and philosophically interesting in their own right, results of this kind of work have pressing, real-world ethical import. For example, based on these kinds of data, Spain recently passed a resolution that legally recognizes and protects of the rights of life, liberty, and freedom from torture for all great apes (Roberts 2008).

Whether some nonhuman animals are capable of mindreading is contentious. In the earliest studies on mindreading in animals, Premack and Woodruff (1978) concluded that their chimpanzee subject, Sarah, was able to attribute mental states to her human handlers. However, objections to the methodology and conclusions were immediate, igniting a dispute that continues to this day (Savage-Rumbaugh et al. 1978; Penn et al. 2008).

Wimmer and Perner (1983), working with human children subjects, reported the first results from what is still considered the litmus test of mindreading, the false belief task. To pass the false belief task, an individual must at least (a) attribute beliefs to others, (b) understand that others' beliefs can differ from her own, and (c) understand that others' beliefs may differ from the true state of the world (i.e., be false). Clearly, passing the false-belief task requires mindreading. Until recently, it was believed that normallydeveloping children fail the task until about the age of three or four (Wellman et al. 2001), however, recent data suggest that infants as young as 13 months can attribute false beliefs (Surian et al. 2007; Buttelmann et al. 2009; Baillargeon et al. 2010).

The first false-belief studies conducted on chimpanzees yielded negative results (Call and Tomasello 1999). But then a number of publications by Hare et al. $(2000,2001)$ and Tomasello et al. (2003) involving food-competition among chimpanzees changed that. The experiment involved two chimpanzees—one dominant, one subordinate-competing for food located in a central area between the 
two subjects. One piece of food, located behind an opaque barrier, was visible only to the subordinate chimpanzee, while another piece of food was visible to both. When the cage doors opened, the subordinate consistently refrained from taking the piece of food that was in the line of sight of the dominant, but did head toward the piece of food occluded from the line of sight of the dominant. The researchers concluded that the inference to best explanation of the observed chimpanzee behavior was to attribute to the subordinate a belief about the mental states of a conspecific, namely, that the dominant could not see the piece of food that was located behind the barrier.

Critics of these conclusions point out what they see as a deep conceptual flaw in the mindreading hypothesis, namely, that since any setup of this kind permits the attribution of mental states to conspecifics based solely on observable features of a conspecific's behavior and environment, it follows that every mindreading hypothesis has a complimentary behavior-reading hypothesis that can equally account for the data (Povinelli and Vonk 2004; Penn et al 2008). This "logical problem" of the mindreading hypothesis remains the greatest challenge to affirmative claims for mindreading in nonhuman animals. ${ }^{26}$ (Lurz 2011).

As mentioned earlier, Kristin Andrews (2012) poses a different critique of mindreading, arguing that the standard view of the folk psychology that underlies the mindreading hypothesis relies on an overly narrow understanding of other minds. Andrews notes that humans employ a variety of methods when explaining the behavior of others, some of which do not require seeing others as having reasons for their actions. According to Andrews, the fact that having the concept of belief is not necessary to predict or explain others' behavior demands a broader, pluralistic account of folk-psychological behavior-explaining mechanisms, one that includes all the practices and competencies associated with social interactions.

Despite these criticisms, research on belief-attribution mindreading in nonhumans remains robust. For example, Krachun et al. (2009) administered a nonverbal false belief task to both chimpanzees and bonobos. Though none of the apes was able to exhibit an understanding of a competitor's false belief, they did, more often than not, look at an unchosen container in false-belief trials, possibly indicating some degree of understanding about a competitor's belief.

There is some evidence that non-great-ape-primates exhibit mindreading behaviors. Flombaum and Santos (2005) observed rhesus macaques selectively "stealing" a grape from an experimenter who was incapable of seeing the grape rather than from an experimenter who appeared visually aware, evidence that rhesus macaques possess the ability to infer what others perceive on the basis of where they are looking.

Herman et al. (1999) argue that dolphins comprehend the referential character of the human pointing gesture and thus, understand the intention of the pointer, and Tschudin $(2001,2006)$ argues that the success of bottlenose dolphins on such belief tasks has considerable ethical and legal implications for animal welfare. Further, Marino et al. (2007) found that cetacean brains contain spindle neurons, believed to be responsible for certain aspects of higher-order social cognition and formerly thought to be unique to humans and great apes.

Other mammals exhibiting evidence of mindreading include dogs (Reid 2009) and even some domestic goats (Kaminski et al. 2005). For example, dogs employ more attention-getting behaviors toward conspecifics when they are facing away with eyes not in direct line of sight (Horowitz 2009). And Scrub jays have recently been shown to exhibit different caching behaviors depending on whether they cache in private or in the presence of a conspecific (Emery et al. 2004; Emery and Clayton 2009). 


\section{From capacities to welfare}

Though other morally relevant cognitive properties exist, this overview has touched on those most salient in both the ethics and scientific literature. I wish now to look at animal welfare policy and legislation in connection with and in light of this overview. That there exists an unfortunate disconnect between most animal welfare policy and legislation, and the science on animal pain, sentience, and cognition is troubling.

\section{Implications for animal welfare}

Animal welfare is best understood as the promotion of physiological, psychological, and species-specific functioning. To promote an animal's welfare, attention must also be paid to the conditions under which the animal lives (Broom 1991). For example, in considering the welfare of a laying hen who spends her life in the tight confines of a battery cage, we must consider her immediate physical condition and health, her possible distressed mental state given the adverse conditions under which she lives (e.g., the difficulties obtaining food, water, exercise, and perhaps, shelter), and any suffering brought on by her inability to express species-typical behaviors, for example, dust bathing.

Though animal welfare concerns arise in such varied human practices as hunting, clothing manufacture, the use of animals in zoos and entertainment, in sport, and as pets, in this section I will focus briefly on just two practices: the raising of animals for food and the use of animals in scientific research. I argue that the moral status of animals as reflected in almost all-even the most progressive-welfare policy is far behind, is ignorant of, or disregards our current and best science on animal sentience and cognition.

\section{Animals raised for food}

\section{Land animals}

According to the USDA Foreign Agricultural Service (2011b), 1.02 billion cattle and 1.2 billion pigs worldwide are raised as livestock, while the number of chickens raised for food worldwide approaches 40 billion. ${ }^{27}$ Most of those animals are raised in Concentrated Animal Feeding Operations (CAFOs) (or "factory farms"). ${ }^{28}$ CAFOs involve raising large numbers of animals in conditions of high density confinement for the production of meat, eggs, and dairy products.

Cattle raised for beef are castrated, dehorned, and branded, all without anesthesia or analgesics. At slaughter, improper stunning techniques can cause some cattle to be hoisted upside down by their hind legs and dismembered while fully conscious. Veal calves are taken from their mothers within a few days of birth, chained in tiny stalls, and fed a nutrient-deficient diet to induce anemia so that their flesh remains pale and tender to the human palette (Rollin 1995).

Sows, who can grow to over $300 \mathrm{~kg}$, live out most of their lives (approximately 4 years) in individual gestation crates measuring approximately $200 \mathrm{~cm}$ by $60 \mathrm{~cm}$ where they give birth to between four to eight litters. Male piglets have their testicles removed, their tails and ears docked, and their teeth clipped, all without anesthesia or analgesics. At slaughter, improper stunning techniques can cause some pigs to reach the scalding bath-intended to soften skin and remove hair-while still conscious (Rollin 1995).

Laying hens live out their lives in battery cages measuring approximately $500 \mathrm{~cm}^{2}$. To prevent stressinduced aggression in chickens caused by overcrowding (such as pecking cagemates (sometimes to death)), the ends of their beaks are cut off with hot blades (a process known as debeaking), without anesthesia or analgesics. Though the normal lifespan of a chicken is approximately 10 years, laying hens on CAFOs are "spent" and unable to produce eggs after just 2 years, at which time they are slaughtered. 
So-called "broiler" chickens are genetically modified so as grow to processing weight in only 6 weeks at which time they are sent to slaughter. At the slaughterhouse, chickens are hung upside-down with their legs snapped into metal shackles, their throats are slit, and they are immersed in scalding hot water for feather removal, often in varying states of consciousness throughout the entire process (Rollin 1995).

\section{Aquaculture}

World demand for fish and fishery products is projected to expand to 183 million metric tonnes by 2015, and it is expected that out of this increase, $73 \%$ will come from aquaculture, accounting for $39 \%$ of global fish production (Ashley 2007). Worldwide figures for the number of sea animals ${ }^{29}$ killed for food are difficult to obtain. One source puts the number of marine animals killed for food in the US alone at 51 billion (FFH 2012).

A number of aquaculture procedures may be inherently stressful for fish and thus compromise fish welfare, including (a) handling and transport which involves (i) removal from the water and air exposure, (ii) the causing of abrasions and the removal of scales (which removes a fish's protective mucous coat), and (iii) excessive weight loading on fish at the bottom of nets and brailles; (b) excessive crowding of fish by increased stock densities; and (c) slaughter techniques including (i) removal from water, (ii) asphyxiation in ice, (iii) asphyxiation in $\mathrm{CO}_{2}$-saturated water, and (iv) gill cutting (Ashley 2007).

\section{Welfare policy}

Intended to decrease suffering of livestock during slaughter, the US Humane Slaughter Act (1995) mandates that animals be made unconsciousness (usually by stunning with a captive bolt gun) prior to slaughter. The Act does not cover the slaughter of rabbits, poultry, fish, or other animals slaughtered for food. The US Animal Welfare Act of 1966 (USAWA) (2010) provides protections for some animals in some circumstances, yet farm animals are excluded from its protections. Though some US states have enacted laws banning gestation crates, veal crates, or battery cages, no federal policy currently exists in the US that regulates the treatment of or protects livestock from the kinds of conditions experienced in CAFOs just described (ALHC 2012).

The European Union has adopted a similar slaughter policy which mandates that animals be made unconsciousness at the time of killing, but the policy goes further, banning battery cages throughout the EU. However, as in the US, no EU current policy regulates the treatment of all living livestock in CAFOs (ALHC 2012).

Regarding fish welfare, despite the fact that organizations such as the Farm Animal Welfare Council (FAWC) have published recommendations regarding the welfare of farmed fish included in the so-called "Five Freedoms," (FAWC 2012), no legislated mandates surrounding aquaculture welfare exist. However, with regard to angling practices, some EU countries have recently banned catch-and-release fishing as cruel (ALHC 2012).

It's unfortunate and troubling that there is a disconnect between most animal welfare policy and legislation on the one hand and the science of animal pain, sentience, and cognition on the other. For example, that the USAWA excludes farm animals from its protections clearly ignores (for reasons of industrial expediency) volumes of scientific data pertaining to the welfare of billions of animals who (as we have seen) are at least sentient. The time for bringing welfare policy for farm animals in line with data from our best science is well-overdue. ${ }^{30}$ 
The use of animals in scientific research

Reliable global figures for animal testing are difficult to obtain, due in large part to the fact that animals bred for research but then killed as surplus and animals used for breeding purposes are not included in tallies. Additionally, tallies of invertebrates and, in the US, rats and mice (which make up about $90 \%$ of research animals) are not required. Figures worldwide range from about 60 to 120 million annually (NCB 2005; USDA 2011a; Taylor et al. 2008).

Scientific research on animals is often divided between basic and applied research. Basic research aims primarily to increase human knowledge and includes behavioral, physiological, developmental, and genetic studies. By contrast, applied research aims to benefit human health in a direct and immediate way and includes the modeling and study of human disease in animals, as well as drug, toxicology, and cosmetic testing (NCB 2005). These different types of research and the procedures associated with them raise questions about necessity, efficacy, and animal welfare.

The USDA (2011a) reports that of the 1,134,693 animals used in scientific research in the US, 697,801 animals (61\%) were used in procedures that involved no pain or distress, 339,769 animals (30\%) were used in procedures that involved pain that was relieved by anesthesia, while 97,123 vertebrate animals (9\%) were used in procedures that involved pain that was not relieved by anesthesia or analgesia. But these figures are deceptively low as they do not include animals not covered under the USAWA such as rats, mice, birds, reptiles, amphibians, or invertebrates (USDA 2010). Conservative estimates put the number of animals used in scientific research in the US who are not covered by the USAWA at 16 million, more than 14 times the total number of animals officially reported used in the US annually (Taylor et al. 2008).

\section{Welfare Policy}

The principles underlying the welfare of animals used in scientific research are known as the "3Rs" of animal research (Russell and Burch 1959) which hold that if animals are to be used in experiments, every effort should be made to Replace them with non-sentient alternatives, Reduce to a minimum the number of animals used, and Refine experiments that use animals so that they minimize pain and distress (Flecknell 2002). A number of countries have passed laws and regulations on the use of animals in scientific research inline with the $3 R S$, though no universal standards are in place.

In the US, Institutional Animal Care and Use Committees (IACUCs) are mandated to review research protocols as prescribed in the Institute for Laboratory Animal Research of the U.S. National Academy of Sciences (2010). Though such guidelines are, in principle, widely adopted, regulation of laboratory animals in the US is legislated only by the USAWA which ensures animals' care and treatment-as long as such regulation does not interfere with the "design, outlines, or guidelines of actual research or experimentation" (1231).

However, the USAWA's definition of 'animal' includes only (but not all) mammals, and excludes

(1) birds, rats of the genus Rattus, and mice of the genus Mus, bred for use in research,

(2) horses not used for research purposes, and (3) other farm animals, such as, but not limited to livestock or poultry, used or intended for use as food or fiber, or livestock or poultry used or intended for use for improving animal nutrition, breeding, management, or production efficiency, or for improving the quality of food or fiber (2132) 
Such an exclusion has no basis in science, having more to do with social and cultural attitudes, and research expediency. ${ }^{31}$

In a positive turn, the Institute of Medicine issued an influential report (2011) on the use of chimpanzees in biomedical and behavioral research. The report guidelines, which were quickly accepted and are now required by the National Institutes of Health (the governmental body responsible for funding biomedical research in the US), advise suspension of all new grants for research on chimpanzees, requiring that the knowledge gained from any further research using chimpanzees must be "necessary to advance the public's health" and that there exist "no other research model by which the knowledge could be obtained." (4)

In contrast to the USAWA, the British Animal Welfare Act (UKAWA) (1986) defines 'animal' as "any living vertebrate, other than man." However, the Act also provides the same protections for one species of octopus (Octopi vulgaris) that it does for all vertebrates. There exists no scientifically reputable reason to single out this particular species of octopus for protection over all the others.

The most inclusive animal welfare act to date is that of India where unregulated experimentation is widely practiced. Though still in the proposal stages, The Animal Welfare Act (2011) defines 'animal' as "any living creature other than a human being." Though constructed with the best of intentions, the Act ignores the science on sentience and cognition and is thus too liberal in scope. Given the wording, the Act protects equally both mammals and microbes.

These cases seem clearly to demonstrate that the moral status of animals as reflected in even the most liberal, progressive welfare policy expresses a severe disconnect from the science on animal sentience and cognition. An exception to these policies is the quite scientifically informed New Zealand's Animal Welfare Act (1999) which protects not only all vertebrates, but "any octopus, squid, crab, lobster, or crayfish (including freshwater crayfish)" or "any other member of the animal kingdom which is declared from time to time by the Governor-General, by Order in Council, to be an animal for the purposes of this Act" as well as "any mammalian foetus, or any avian or reptilian pre-hatched young, that is in the last half of its period of gestation or development." Perhaps future policies might model the NZ Act.

\section{Conclusion}

This brief review of the ethical and scientific literature regarding the questions, 'Which animals possess which morally relevant intrinsic properties, and to what extent?' has adequately answered neither. Given the subjective nature of many of the phenomenal aspects of these properties, robust epistemological certainty regarding such capacities in nonhuman animals seems contingent upon solving the mind-body problem. Yet, for issues of practical moral import, such degrees of certainty are not required.

The best we can do then is to continue to investigate these questions with scientific rigor and incorporate into our moral theories and ethical practices those findings that have ethical significance. In many instances, adopting the precautionary principle so as to avoid presumptions about and potentially harmful consequences of human exceptionalism seems prudent. Most philosophers currently writing on the moral status of animals understand the indispensability of such scientific findings, yet current legislation and policy regarding animal welfare egregiously trails behind our best science on animal sentience and cognition, reflecting ignorance of and a serious discontinuity with such findings. We owe it to the billions of sentient beings held in captivity to formulate scientifically literate moral theory and to protect the interests of nonhuman animals by legislating reasoned, scientifically informed welfare policy. 


\section{Notes}

1 I will use the terms 'animals' and 'nonhuman animals' interchangeably throughout the paper to refer to nonhuman animals.

2 See Gruen (2011), chapter one, for a clear and thorough discussion and analysis of human exceptionalism.

3 See, for example (Humphrey 2002).

4 For a quite forceful defense of the attribution of mental states to nonhuman animals, see Andrews (2009).

5 Endorphins and encephalins are two of the more common substances-found in many organismsknown to have morphine-like analgesic effects.

6 Noxious stimuli used in pain research on nonhumans include mechanical (pricking or probing), thermal (heating or freezing), chemical (exposure to acidic irritants), and electrical (shocking).

7 Dawkins (2006) presents a clear and persuasive analysis of the scientific basis for assessing suffering in animals, highlighting the plurality of mental states that might be properly described as 'suffering', and thus somewhat vaguely (and I think, wisely) characterizes suffering as the "experiencing one of a wide range of extremely unpleasant subjective (mental) states," (2006: 28), a definition I wholly endorse.

8 For clear discussions of some of the difficulties peculiar to assessing animal pain, see Allen (2004, 2005).

9 For a nice discussion of the difficulties in finding a unified theory of pain, see Aydede's Introduction to his (Aydede 2005).

10 See Grahek (2007) for quite a thorough analysis of the empirical literature on such pain abnormalities and the implications of such data for the "hard problem" of consciousness in the context of pain.

11 See the World Society for the Protection of Animals (WSPA) website Sentience Mosaic (WSPA 2012) for an exhaustive number of resources on the scientific literature on nonhuman animal sentience and its connection to animal welfare issues.

12 See, for example (Carruthers 1992 and Rose 2007).

13 See, for example (Rose 2002).

14 See, for example (Agger 2009).

15 See Braithwaite (2010), Utrecht (2010).

16 Interestingly, Eisemann advises the "experimental biologist. . . to follow, whenever feasible, Wigglesworth's recommendation that insects have their nervous systems inactivated prior to traumatizing manipulation. This procedure not only facilitates handling, but also guards against the remaining possibility of pain infliction and, equally important, helps to preserve in the experimenter an appropriately respectful attitude towards living organisms whose physiology, though different, and perhaps simpler than our own, is as yet far from completely understood" (167).

17 See, for example (Wallace 2004) and (Sample 2007).

18 Serving an adaptive function as part of the body's fight-or-flight response, fear is believed to operate in a more primitive subcortical brain circuit than pain. For example, when the cortex of an animal is removed, it appears no longer to suffer pain, yet still appears capable of learning a conditional fear response (Grandin 2003).

19 See Huntingford et al. (2006) for a through review of fish welfare issues.

20 Interestingly, in July of 2012, scientists gathered at the University of Cambridge for the first annual Francis Crick Memorial Conference, "Consciousness in Human and Non-Human Animals," and produced the The Cambridge Declaration on Consciousness (Low 2012). The declaration concludes that "non-human animals have the neuroanatomical, neurochemical, and neurophysiological substrates of conscious states along with the capacity to exhibit intentional behaviors. Consequently, the weight of evidence indicates that humans are not unique in possessing the neurological 
substrates that generate consciousness. Non-human animals, including all mammals and birds, and many other creatures, including octopuses, also possess these neurological substrates." calls biocentric anthropomorphism, the indispensable use of human terms to explain animals' mental lives, emotions, or feelings. However, Marian Stamp Dawkins (2012) attacks even this kind of anthropocentrism as too prevalent in the scientific literature, ultimately harming the cause of animal welfare.

For an extensive review of the manifold criteria and arguments for self-awareness in nonhuman animals (a phenomenon (rightly) characterized not as a single but as a complex phenomenon), see DeGrazia (2009).

23 Bekoff (2001) describes what he calls the "yellow snow" test intended to evaluate a certain level of self/other differentiation in dogs. According to Bekoff, dogs have some of the same aspects of selfawareness that humans have, for example, a kind of "body-ness" (or proprioceptive sense), and a somewhat territorial/ownership sense of "mine-ness." However, Bekoff does not believe the data yet support in dogs robust self-awareness. For a novel defense of the view that MSR shows self-awareness see Savanah (2012).

25 For example, semantic, episodic, and procedural. See Tulving (1985) for a thorough taxonomy.

26 For a sophisticated and persuasive response to "Povinelli's challange" see Andrews (2005).

27 The focus of this section will be on cattle, pigs, and chicken. Other land animals produced in mass numbers for food and clothing include sheep, horses, rabbits, turkeys, fur mammals, and others. Data on this latter group is not as readily available as on the former.

28 For details on CAFOs see Eisnitz (1997), Imhoff (2010), Kirby (2010).

29 'Sea animals' includes so-called "finfish" and shellfish, but excludes other kinds of marine species killed for food, e.g., marine mammals, eels, etc.

30 See Dantzer (2002) for what seems a reasonable and workable research agenda on emotion and cognition in farm animals that would help us understand their welfare requirements.

31 Since these taxa are not covered under the Act, research facilities are not required to keep numbers on the use of such animals, thus accurate figures for the number used in US research facilities go unreported. See Greek and Greek (2000) for a thorough and insightful analysis of the "animal research-industrial complex."

\section{Acknowledgments}

This research was financially supported in part by a Summer Fellowship from the Animal and Society Institute-Wesleyan Animal Studies (ASI-WAS). I would like to thank ASI-WAS and my ASI-WAS Fellows for their helpful input on this work. I would also like to thank Sara Trechter, Alexandra Horowitz, an anonymous referee, and especially Lori Gruen for their thorough and substantive comments, and Aimin Chen for helpful editorial suggestions on an early draft of this paper. Thanks also to Peter Godfrey-Smith and Kim Sterelny.

\section{References}

Abbott D, Keverne E, Bercovitch F, Shively C, Mendoza S, Saltzman W, Snowdon C, Ziegler T, Banjevic M, Jr TG, Sapolsky R (2003) Are subordinates always stressed? a comparative analysis of rank differences in cortisol levels among primates. Horm Behav 43(1):67-82. doi:10.1016/S0018506X(02)00037-5

Abeyesinghe S, Nicol C, Hartnell S, Wathes C (2005) Can domestic fowl, gallus gallus domesticus, show self-control? Animal Behav 70(1):1-11. doi:10.1016/j.anbehav.2004.10.011, URL http://www.sciencedirect.com/science/article/pii/S0003347205000412 
Agger M (2009) Frying nemo: do fish feel pain? Slate

ALHC (2012) International comparative animal cruelty laws. http://www.animallaw.info/articles/ddusicacl.htm\#IV , accessed: April 1, 2012

Allen C (2004) Animal pain. Noûs 38(4):617-643 doi:10.1111/j.0029-4624.2004.00486.x

Allen C (2005) Deciphering animal pain. In: Pain: new essays on its nature and the methodology of its study, Bradford Book/MIT Press, Cambridge, MA

Allen C (2010) How should we interpret research on mental capacities in fish species? http://www.uu.nl/SiteCollectionDocuments/GW/GW Agenda/2010/20101129-expert-meeting-fishwelfare.pdf

Altevogt BM, Pankevich DE, Shelton-Davenport MK, Kahn JP (2011) Chimpanzees in biomedical and behavioral research: assessing the necessity. National Academies Press, Washington, DC. URL http://www.nap.edu/catalog.php?record id=13257

Anderson JR, Gallup GG Jr (2011) Which primates recognize themselves in mirrors?. PLoS Biol 9(3):e1001024. doi:10.1371/journal.pbio.1001024

Andrews K (2005) Chimpanzee theory of mind: Looking in all the wrong places? Mind Lang 20(5):521536 doi:10.1111/j.0268-1064.2005.00298.x

Andrews K (2009) Politics or metaphysics? on attributing psychological properties to animals. Biol Philos 24:51-63. doi:10.1007/s10539-007-9098-2

Andrews K (2012) Do apes read minds?: Toward a new folk psychology. MIT Press, Cambridge, MA

Asendorpf JB, Warkentin V, Baudonnie're PM (1996) Self-awareness and other-awareness. ii: Mirror selfrecognition, social contingency awareness, and synchronic imitation. Dev Psychol 32(2):313-321. URL

http://mantis.csuchico.edu/login?url=http://search.ebscohost.com/login.aspx?direct=true\&db=pdh\&AN $=$ dev-32-2-313\&site=ehost-live

Ashley PJ (2007) Fish welfare: current issues in aquaculture. Appl Animal Behav Sci 104(3-4):199-235. doi:10.1016/j.applanim.2006.09.001. http://www.sciencedirect.com/science/article/pii/S0168159106002954

AWBI (2011) Animal welfare act of 2011. http://moef.nic.in/downloads/public-information/draftanimalwelfare-act-2011.pdf, Animal Welfare Board of India, http://moef.nic.in/downloads/publicinformation/draft-animal-welfare-act-2011.pdf

Aydede M (2005) Pain: new essays on its nature and the methodology of its study. MIT Press, Cambridge, MA. URL http://www.loc.gov/catdir/toc/fy0702/2005042146.html

Babb SJ, Crystal JD (2006) Episodic-like memory in the rat. Curr Biol 16(13):1317-1321. doi: 10.1016/j.cub.2006.05.025, http://www.sciencedirect.com/science/article/pii/S0960982206016083

Baillargeon R, Scott RM, He Z (2010) False-belief understanding in infants. Trends Cogn Sci 14(3):110118. URL http://www.sciencedirect.com/science/article/pii/S1364661309002885 
Barr S, Laming PR, Dick JT, Elwood RW (2008) Nociception or pain in a decapod crustacean? Animal Behav 75(3):745-751. doi:10.1016/j.anbehav.2007.07.004, URL http://www.sciencedirect.com/science/article/pii/S0003347207004332

Basile BM, Hampton RR (2011) Monkeys recall and reproduce simple shapes from memory. Curr Biol 21(9):774-778. doi:10.1016/j.cub.2011.03.044

Bekoff M (2000) Animal emotions: exploring passionate natures. BioScience 50(10):861-870. URL http://www.jstor.org/stable/10.1641/0006568\%282000\%29050\%5B\%0861\%3AAEEPN\%5D2.0.CO\%3B2

Bekoff M (2001) Observations of scent-marking and discriminating self from others by a domestic dog (canis familiaris): tales of displaced yellow snow. Behav Process 55(2):75-79. doi:10.1016/S03766357(01)00142-5

Birkett LP, Newton-Fisher NE (2011) How abnormal is the behaviour of captive, zoo-living chimpanzees? PLoS ONE 6(6):e20101. doi:10.1371/journal.pone.0020101

Bradshaw GA (2009) Elephants on the edge: what animals teach us about humanity. Yale University Press, New Haven

Bradshaw GA, Schore AN, Brown JL, Poole JH, Moss CJ (2005) Elephant breakdown. Nature 433(7028): 807. URL http://mantis.csuchico.edu/login?url=http://search.ebscohost.com/login.aspx?direct $=$ true $\& d b=a p h \& A N=16201517 \&$ site $=$ ehost-live

Braithwaite V (2010) Do fish feel pain? Oxford University Press, Oxford

Braithwaite VA, Boulcott P (2008) Can fish suffer? In: Branson EJ (ed) Fish welfare. Blackwell Publishing Ltd, Oxford, pp 78-92

Broom DM (1991) Animal welfare: concepts and measurement. J Animal Sci 69(10):4167-4175. URL http://jas.fass.org/content/69/10/4167.abstract, http://jas.fass.org/content/69/10/4167.full.pdf?html

Broom DM, Sena H, Moynihan KL (2009) Pigs learn what a mirror image represents and use it to obtain information. Animal Behav 78(5):1037-1041. doi:10.1016/j.anbehav.2009.07.027. URL http://www.sciencedirect.com/science/article/pii/S0003347209003571

Brown C, Krause J, Laland KN (2011) Fish cognition and behavior, fish and aquatic resources series, vol 15, 2nd edn. Wiley-Blackwell, Chichester, West Sussex, UK

Buttelmann D, Carpenter M, Tomasello M (2009) Eighteen-month-old infants show false belief understanding in an active helping paradigm. Cognition 112(2):337-342. URL http://www.sciencedirect.com/science/article/pii/S0010027709001115

Call J, Tomasello M (1999) A nonverbal false belief task: the performance of children and great apes. Child Dev 70(2):381-395. doi:10.1111/1467-8624.00028

Carruthers $\mathrm{P}$ (1992) The animals issue: moral theory in practice. Cambridge University Press, Cambridge. URL http://www.loc.gov/catdir/description/cam025/92009338.html 
Chandroo K, Duncan I, Moccia R (2004) Can fish suffer?: perspectives on sentience, pain, fear and stress. Appl Animal Behav Sci 86(3-4):225-250. doi:10.1016/j.applanim.2004.02.004, URL http://www.sciencedirect.com/science/article/pii/S0168159104000498

Cheney DL, Seyfarth RM (2007) Baboon metaphysics: the evolution of a social mind. University of Chicago Press, Chicago. URL http://www.loc.gov/catdir/toc/ecip077/2006102646.html

Clayton NS, Dickinson A (1998) Episodic-like memory during cache recovery by scrub jays. Nature 395(6699):272-274. URL http://dx.doi.org/10.1038/26216

Couchman JJ (2012) Self-agency in rhesusmonkeys. Biol Lett 8(1):39-41. doi:10.1098/rsbl.2011.0536. URL $\quad$ http://rsbl.royalsocietypublishing.org/content/8/1/39.abstract, http://rsbl.royalsocietypublishing.org/content/8/1/39.full.pdf?html

Crystal JD (2009) Elements of episodic-like memory in animal models. Behav Process 80(3):269-277. doi:10.1016/j.beproc.2008.09.009, URL http://www.sciencedirect.com/science/article/pii/S0376635708002210

Culloty SC, Mulcahy MF (1992) An evaluation of anaesthetics for ostrea edulis (I.). Aquaculture 107(2-3): 249-252. doi:10.1016/0044-8486(92)90073-T. http://www.sciencedirect.com/science/article/pii/004484869290073T

Dalton L, Widdowson P (1989) The involvement of opioid peptides in stress-induced analgesia in the slug arion ater. Peptides 10(1):9-13. doi:10.1016/0196-9781(89)90067-3

Dantzer R (2002) Can farm animal welfare be understood without taking into account the issues of emotion and cognition? J Animal Sci 80(E-Suppl 1):E1-E9. URL http://jas.fass.org/content/80/ESuppl 1/E1.short, http://jas.fass.org/content/80/E-Suppl 1/E1.full.pdf?html

Dawkins MS (2006) The scientific basis for assessing suffering in animals. In: Singer P (ed) In defense of animals: the second wave. Blackwell, Malden, MA

Dawkins MS (2012) Why animals matter: animal consciousness, animal welfare and human well-being. Oxford University Press, Oxford

DeGrazia D (2009) Self-awareness in animals. In: Lurz RW (ed) The Philosophy of animal minds. Cambridge University Press, Cambridge, UK, pp 201-217

Delfour F, Marten K (2001) Mirror image processing in three marine mammal species: killer whales (orcinus orca), false killer whales (pseudorca crassidens) and california sea lions (zalophus californianus). Behav Process 53(3):181-190. doi:10.1016/S0376-6357(01)00134-6

Dennett D (1976) Conditions of personhood. In: The identities of persons. Topics in philosophy; v. 3, University of California Press, Berkeley, pp 175-196

Dere E, Kart-Teke E, Huston J, Silva MDS (2006) The case for episodic memory in animals. Neurosci Biobehav Rev 30(8):1206-1224. doi:10.1016/j.neubiorev.2006.09.005, URL http://www.sciencedirect.com/science/article/pii/S0149763406001059

Dyakonova VE (2001) Role of opioid peptides in behavior of invertebrates. J Evol Biochem Physiol 37:335-347. doi:10.1023/A:1012910525424 
Dyakonova VE, Schu"rmann F, Sakharov DA (1999) Effects of serotonergic and opioidergic drugs on escape behaviors and social status of male crickets. Naturwissenschaften 86(9):435-437

Eacott MJ, Easton A, Zinkivskay A (2005) Recollection in an episodic-like memory task in the rat. Learn $\begin{array}{lll}\text { Memory 12(3):221-223. doi:10.1101/lm.92505. URL } & \end{array}$ http://learnmem.cshlp.org/content/12/3/221.abstract, http://learnmem.cshlp.org/content/12/3/221.full.pdf?html

Eisemann CH, Jorgensen WK, Merritt DJ, Rice MJ, Cribb BW, Webb PD, Zalucki MP (1984) Do insects feel pain?-A biological view. Cell Mol Life Sci 40(2):164-167. doi:10.1007/BF01963580

Eisner T, Camazine S (1983) Spider leg autotomy induced by prey venom injection: an adaptive response to "pain"? Proc Natl Acad Sci 80(11):3382-3385. URL http://www.pnas.org/content/80/11/3382.abstract, http://www.pnas.org/content/80/11/3382.full.pdf?html

Eisnitz GA (1997) Slaughterhouse: the shocking story of greed, neglect, and inhumane treatment inside the U.S. meat industry. Prometheus Books, Amherst, N.Y. URL http://www.loc.gov/catdir/toc/ecip0617/2006022924.html

Elwood RW, Appel M (2009) Pain experience in hermit crabs? Animal Behav 77(5):1243-1246. doi: 10.1016/j.anbehav.2009.01.028.

URL http://www.sciencedirect.com/science/article/pii/S0003347209000712

Emery N, Dally J, Clayton N (2004) Western scrub-jays (Aphelocoma californica) use cognitive strategies to protect their caches from thieving conspecifics. Animal Cogn 7:37-43. doi: 10.1007/s10071-0030178-7

Emery NJ, Clayton NS (2009) Comparative social cognition. Annual Rev Psychol 60(1):87-113. doi: 10.1146/annurev.psych.60.110707.163526

FAWC (2012) Report on the welfare of farmed fish. http://www.fawc.org.uk/reports/fish/fishrtoc.htm . Accessed: April 1, 2012

Ferdowsian HR, Durham DL, Kimwele C, Kranendonk G, Otali E, Akugizibwe T, Mulcahy JB, Ajarova L, Johnson CM (2011) Signs of mood and anxiety disorders in chimpanzees. PLoS ONE 6(6):e19855. doi:10.1371/journal.pone.0019855

FFH (2012) Free from harm. website, URL http://freefromharm.org/farm-animal-welfare/59-billionlandand-sea-animals-killed-for-food-in-the-us-in-2009/

Flecknell P (2002) Replacement, reduction and refinement. ALTEX 19(2):73-78

Flombaum JI, Santos LR (2005) Rhesus monkeys attribute perceptions to others. Curr Biol 15(5): 447452. doi:10.1016/j.cub.2004.12.076.

URL http://www.sciencedirect.com/science/article/pii/S0960982205000989

Gallup G, Anderson JR, Shillito DJ (2002) The mirror test. In: Bekoff M, Allen C, Burghardt GM (eds) The cognitive animal: empirical and theoretical perspectives on animal cognition. MIT Press, Cambridge, MA, pp 325-333 
Gallup GG (1970) Chimpanzees: self-recognition. Science 167(3914):86-87. doi:10.1126/science.167.3914.86

GOASPA (1986) Guidance on the operation of the animals (scientific procedures) act 1986. http://www.archive.official-documents.co.uk/document/hoc/321/321.htm , British Secretary of State for the Home Department. http://www.archive.official-documents.co.uk/document/hoc/321/321.htm

Grahek N (2007) Feeling pain and being in pain, 2nd edn. MIT Press, Cambridge, MA. URL http://www.loc.gov/catdir/toc/ecip071/2006030376.html

Grandin T (2003) Distress in animals: Is it fear, pain or physical stress? American Board of Veterinary Practitioners

Greek CR, Greek JS (2000) Sacred cows and golden geese: the human cost of experiments on animals. Continuum, New York

Griffin DR (1976) The question of animal awareness: evolutionary continuity of mental experience. Rockefeller University Press, New York

Gruen L (2011) Ethics and animals: an introduction. Cambridge applied ethics, Cambridge University Press, Cambridge, UK. URL http://assets.cambridge.org/97805218/88998/cover/9780521888998.jpg

Hare B, Call J, Agnetta B, Tomasello M (2000) Chimpanzees know what conspecifics do and do not see. Animal Behav 59(4):771-785. doi:10.1006/anbe.1999.1377, URL http://www.sciencedirect.com/science/article/pii/S0003347299913775

Hare B, Call J, Tomasello M (2001) Do chimpanzees know what conspecifics know? Animal Behav 61(1):139-151. doi:10.1006/anbe.2000.1518. URL http://www.sciencedirect.com/science/article/pii/S0003347200915185

Henderson J, Hurly TA, Bateson M, Healy SD (2006) Timing in free-living rufous hummingbirds, selasphorus rufus. Curr Biol 16(5):512-515. doi:10.1016/j.cub.2006.01.054. URL http://www.sciencedirect.com/science/article/pii/S0960982206010931

Herman LM, Abichandani SL, Elhajj AN, Herman EYK, Sanchez JL, Pack AA (1999) Dolphins (tursiops truncatus) comprehend the referential character of the human pointing gesture. $\mathrm{J}$ Comp Psychol 113(4):347-364. doi:10.1037/0735-7036.113.4.347

Hochner B, Shomrat T, Fiorito G (2006) The octopus: a model for a comparative analysis of the evolution of learning and memory mechanisms. Biol Bull 210:308-317

Horner V, Whiten A (2005) Causal knowledge and imitation/emulation switching in chimpanzees (Pan troglodytes) and children (Homo sapiens). Animal Cogn 8:164-181. doi:10.1007/s10071-004-0239-6

Horowitz A (2009) Attention to attention in domestic dog (Canis familiaris) dyadic play. Animal Cogn 12:107-118. doi:10.1007/s10071-008-0175-y

Humphrey N (2002) The inner eye. Oxford University Press, Oxford. URL http://www.loc.gov/catdir/ enhancements/fy0614/2002727756-d.html

Huntingford FA, Adams C, Braithwaite VA, Kadri S, Pottinger TG, Sandøe P, Turnbull JF (2006) Current issues in fish welfare. J Fish Biol 68(2):332-372. doi:10.1111/j.0022-1112.2006.001046.x 
Imhoff D (ed) (2010) The cafo reader: the tragedy of industrial animal factories, 1st edn. Watershed Media, Healdsburg, CA

Janik VM, Sayigh LS, Wells RS (2006) Signature whistle shape conveys identity information to bottlenose dolphins. Proc Natl Acad Sci USA 103(21):8293-8297. doi:10.1073/pnas.0509918103

Kaminski J, Riedel J, Call J, Tomasello, M. (2005) Domestic goats, capra hircus, follow gaze direction and use social cues in an object choice task. Animal Behav 69(1):11-18. doi:10.1016/j.anbehav.2004.05.008. http://www.sciencedirect.com/science/article/pii/S0003347204003264

Kavaliers M, Ossenkopp K (1991) Opioid systems and magnetic field effects in the land snail, cepaea nemoralis. Biol Bull 180:301-309

Kirby D (2010) Animal factory: the looming threat of industrial pig, dairy, and poultry farms to humans and the environment, 1st edn. St. Martin's Press, New York. URL http://www.loc.gov/catdir/enhancements/fy1013/2009039692-b.html

Krachun C, Carpenter M, Call J, Tomasello M (2009) A competitive nonverbal false belief task for children and apes. Dev Sci 12(4):521-535. doi:10.1111/j.1467-7687.2008.00793.x

Low P (2012) The cambridge declaration on consciousness. URL http://fcmconference.org/img/CambridgeDeclarationOnConsciousness.pdf

Lozada M, Romano A, Maldonado H (1988) Effect of morphine and naloxone on a defensive response of the crab chasmagnathus granulatus. Pharmacol Biochem Behav 30(3):635-640. doi:10.1016/00913057(88)90076-7

Lurz RW (2011) Mindreading animals: the debate over what animals know about other minds. MIT Press, Cambridge, MA

Marino L, Connor RC, Fordyce RE, Herman LM, Hof PR, Lefebvre L, Lusseau D, McCowan B, Nimchinsky EA, Pack AA, Rendell L, Reidenberg JS, Reiss D, Uhen MD, Van der Gucht E, Whitehead H (2007) Cetaceans have complex brains for complex cognition. PLoS Biol 5(5):e139. doi:10.1371/journal.pbio.0050139

Martin-Ordas G, Haun D, Colmenares F, Call J (2010) Keeping track of time: evidence for episodic-like memory in great apes. Animal Cogn 13:331-340. doi:10.1007/s10071-009-0282-4

Merskey H, Bogduk N (1994/2011) Classification of chronic pain: descriptions of chronic pain syndromes and definitions of pain terms, 2nd edn. IASP Press, Seattle

Mitchell R (1994) Humans, nonhumans, and persons. In: Cavalieri P, Singer P (eds) The great ape project: equality beyond humanity. St. Martin's Press, New York, pp 237-247

NCB (2005) The ethics of research involving animals. Tech. rep., Nuffield council on bioethics. http://www. nuffieldbioethics.org/sites/default/files/The\%20ethics\%20of\%20research\%20involving\%20 animals\%20-\%20full\%20report.pdf

Neely GG, Keene AC, Duchek P, Chang EC, Wang QP, Aksoy YA, Rosenzweig M, Costigan M, Woolf CJ, Garrity PA, Penninger JM (2011) TrpA1\&lt regulates thermal nociception in Drosophila. PLoS ONE 6(8):e24343. doi:10.1371/journal.pone.0024343 
Nordgreen J, Garner JP, Janczak AM, Ranheim B, Muir WM, Horsberg TE (2009) Thermonociception in fish: effects of two different doses of morphine on thermal threshold and post-test behaviour in goldfish (carassius auratus). Appl Animal Behav Sci 119(2):101-107. doi:10.1016/j.applanim.2009.03.015. http://www.sciencedirect.com/science/article/pii/S0168159109001051

$\begin{array}{lllll}\text { NZAWA } & \text { (1999) } & \text { Animal } & \text { welfare } & \text { act }\end{array}$ http://www.legislation.govt.nz/act/public/1999/0142/latest/DLM49664.html , New Zealand Ministry of Agriculture and Forestry. http://www.legislation.govt.nz/act/public/1999/0142/latest/DLM49664.html

OLAW (2010) Guide for the care and use of laboratory animals, 8th edn. National Academy Press, Washington, DC

Pahl M, Zhu H, Pix W, Tautz J, Zhang S (2007) Circadian timed episodic-like memory-a bee knows what to do when, and also where. J Exp Biol 210(20):3559-3567. doi:10.1242/jeb.005488. URL http://jeb.biologists.org/content/210/20/3559.abstract, http://jeb.biologists.org/content/210/20/3559.full.pdf?html

Patterson F, Cohn R (1994) Self-recognition and self-awareness in lowland gorillas. In: Parker ST, Mitchell RW, Boccia M (eds) Self-awareness in animals and humans: developmental perspectives. Cambridge University Press, Cambridge, pp 273-290

Paukner A, Suomi SJ, Visalberghi E, Ferrari PF (2009) Capuchin monkeys display affiliation toward humans who imitate them. Science 325(5942):880-883. doi:10.1126/science.1176269. URL http://www.sciencemag.org/content/325/5942/880.abstract, http://www.sciencemag.org/content/325/5942/880.full.pdf

Penn DC, Holyoak KJ, Povinelli DJ (2008) Darwin's mistake: explaining the discontinuity between human and nonhuman minds. Behav Brain Sci 31(2):109-130; discussion 130-178. doi: $10.1017 /$ S0140525X08003543

Plotnik JM, de Waal FBM, Reiss D (2006) Self-recognition in an asian elephant. Proc Natl Acad Sci 103(45):17053-17057. doi:10.1073/pnas.0608062103.

URL http://www.pnas.org/content/103/45/17053.abstract, http://www.pnas.org/content/103/45/17053.full.pdf?html

Posada S, Colell M (2007) Another gorilla (gorilla gorilla gorilla) recognizes himself in a mirror. Am J Primatol 69(5):576-583. doi:10.1002/ajp.20355

Povinelli DJ, Vonk J (2004) We don't need a microscope to explore the chimpanzee's mind. Mind Lang 19(1):1-28. doi:10.1111/j.1468-0017.2004.00244.x

Povinelli DJ, Rulf AB, Landau KR, Bierschwale DT (1993) Self-recognition in chimpanzees (pan troglodytes): distribution, ontogeny, and patterns of emergence. J Comp Psychol 107(4):347-372

Premack D, Woodruff G (1978) Does the chimpanzee have a theory of mind? Behav Brain Sci 4:515-526

Prior H, Schwarz A, Güntürkün O (2008) Mirror-induced behavior in the magpie (pica pica): evidence of self-recognition. PLoS Biol 6(8):e202. doi:10.1371/journal.pbio.0060202 
Rajala AZ, Reininger KR, Lancaster KM, Populin LC (2010) Rhesus monkeys (Macaca mulatta) do recognize themselves in the mirror: Implications for the evolution of self-recognition. PLOS ONE 5(9):e12865. doi:10.1371/journal.pone.0012865

Regan T (1983) The case for animal rights. University of California Press, Berkeley

Reid PJ (2009) Adapting to the human world: Dogs' responsiveness to our social cues. Behav Process 80(3):325-333. doi:10.1016/j.beproc.2008.11.002. URL http://www.sciencedirect.com/science/article/pii/S0376635708002623

Reiss D, Marino L (2001) Mirror self-recognition in the bottlenose dolphin: a case of cognitive convergence. Proc Natl Acad Sci USA 98(10):5937-5942. doi:10.1073/pnas.101086398

Roberts M (2008) Spanish parliament to extend rights to apes. Reuters URL http://www.reuters.com/article/2008/06/25/us-spain-apes-idUSL256586320080625

Rogers LJ, Kaplan G (2004) All animals are not equal: the interface between scientific knowledge and legislation for animal rights. In: Sunstein MC, Cass R, Nussbaum (eds) Animal rights. Oxford University Press, Oxford, pp 175-202

Rollin BE (1981) Animal rights and human morality. Prometheus Books, Buffalo, NY

Rollin BE (1995) Farm animal welfare: social, bioethical, and research issues, 1st edn. lowa State University Press, Ames

Rose JD (2002) The neurobehavioral nature of fishes and the question of awareness and pain. Rev Fis Sci 10(1):1-38 doi:10.1080/20026491051668

Rose JD (2007) Anthropomorphism and 'mental welfare' of fishes. Dis Aquat Organ 75(2):139-154

Ross LG, Ross B (2008) Anaesthetic and sedative techniques for aquatic animals, 3rd edn. Blackwell, Oxford. URL http://www.loc.gov/catdir/enhancements/fy0805/2007039121-b.html

Russell WMS, Burch RL (1959) The principles of humane experimental technique. Methuen, London

Salwiczek LH, Watanabe A, Clayton NS (2010) Ten years of research into avian models of episodic-like memory and its implications for developmental and comparative cognition. Behav Brain Res 215(2):221-234. doi:10.1016/j.bbr.2010.06.011. URL http://www.sciencedirect.com/science/article/pii/S0166432810004559

Sample I (2007) Blow for fans of boiled lobster: crustaceans feel pain, study says. The Guardian p p 6

Sapolsky RM (2005) The influence of social hierarchy on primate health. Science 308(5722):648-652. doi: 10.1126/science.1106477. URL http://www.sciencemag.org/content/308/5722/648.abstract, http://www.sciencemag.org/content/308/5722/648.full.pdf

Savage-Rumbaugh S, Savage D, Boysen S (1978) Sarah's problems in comprehension. Behav Brain Sci 4:555-557

Savanah S (2012) Mirror self-recognition and symbol-mindedness. Biol Philos 1-17. doi:10.1007/s10539012-9318-2 
Schilhab TS (2004) What mirror self-recognition in nonhumans can tell us about aspects of self. Biol Philos 19(1):111-126. doi:10.1023/B:BIPH.0000013249.23475.1f

Setchell JM, Smith T, Wickings EJ, Knapp LA (2010) Stress, social behaviour, and secondary sexual traits in a male primate. Horm Behav 58(5):720-728. doi:10.1016/j.yhbeh.2010.07.004. URL http://www.sciencedirect.com/science/article/pii/S0018506X1000200X

Shumaker R, Swartz K (2002) When traditional methodologies fail: Cognitive studies of great apes. In: Bekoff M, Allen C, Burghardt GM (eds) The cognitive animal: empirical and theoretical perspectives on animal cognition. MIT Press, Cambridge, MA, pp 335-343

Singer P (1975) Animal liberation: a new ethics for our treatment of animals. A New York review book, New York review, New York

Smith E, Lewin G (2009) Nociceptors: a phylogenetic view. J Comp Physiol A Neuroethol Sens Neural Behav Physiol 195:1089-1106. doi:10.1007/s00359-009-0482-z

Sneddon LU (2003) The evidence for pain in fish: the use of morphine as an analgesic. Appl Animal Behav Sci 83(2):153-162. doi:10.1016/S0168-1591(03)00113-8

Sneddon LU (2007) Assessing pain perception in fish from physiology to behaviour. Comp Biochem Physiol A Mol Integr Physiol 146(4, Supplement):S78. doi:10.1016/j.cbpa.2007.01.092. URL http://www.sciencedirect.com/science/article/pii/S1095643307001547, abstracts of the annual main meeting of the society for experimental biology, Glasgow, Scotland, 31st March-4th April, 2007

Sneddon LU, Braithwaite VA, Gentle MJ (2003a) Do fishes have nociceptors? evidence for the evolution of a vertebrate sensory system. Proc Biol Sci 270(1520):1115-1121. doi:10.1098/rspb.2003.2349

Sneddon LU, Braithwaite VA, Gentle MJ (2003b) Novel object test: examining nociception and fear in the rainbow trout. $\quad J \quad$ Pain $4(8): 431-440 . \quad$ URL http://www.sciencedirect.com/science/article/pii/S152659000300717X

Surian L, Caldi S, Sperber D (2007) Attribution of beliefs by 13-month-old infants. Psychol Sci 18(7):580586. doi:10.1111/j.1467-9280.2007.01943.x. URL http://pss.sagepub.com/content/18/7/580.abstract , http://pss.sagepub.com/content/18/7/580.full.pdf?html

Taylor K, Gordon N, Langley G, Higgins W (2008) Estimates for worldwide laboratory animal use in 2005. Altern Lab Anim 36(3):327-342

Tobin DM, Bargmann Cl (2004) Invertebrate nociception: behaviors, neurons and molecules. J Neurobiol 61(1):161-174. doi:10.1002/neu.20082

Tomasello M, Call J, Hare B (2003) Chimpanzees understand psychological states-the question is which ones and to what extent. Trends Cogn Sci 7(4):153-156. doi:10.1016/S1364-6613(03)00035-4

Tracey WD, Wilson RI, Laurent G, Benzer S (2003) painless, a drosophila gene essential for nociception. Cell 113(2):261-273. doi:10.1016/S0092-8674(03)00272-1

Tschudin A (2001) 'mindreading' mammals? attribution of belief tasks with dolphins. Animal Welfare 10(Supplement 1):119-127.

URL http://www.ingentaconnect.com/content/ufaw/aw/2001/00000010/A00101s1/art00011 
Tschudin A (2006) Belief attribution tasks with dolphins: What social minds can reveal about animal rationality. In: Hurley SL, Nudds M (eds) Rational animals? Oxford University Press, Oxford, pp 413436

Tulving E (1985) How many memory systems are there? Am Psychol 40(4):385-398

Turving E (2005) Episodic memory and autonoesis: uniquely human? In: Terrace HS, Metcalfe J (eds) The missing link in cognition: origins of self-reflective consciousness. Oxford University Press, Oxford, pp 3-56

USDA (2010) Animal welfare act. http://awic.nal.usda.gov/government-and-professionalresources/federal-laws/animal-welfare-act, USDA, http://awic.nal.usda.gov/government-andprofessionalresources/federal-laws/animal-welfare-act

USDA (2011a) Annual report animal usage by fiscal year. http://www.aphis.usda.gov/animal welfare/efoia/downloads/2009 Animals Used In Research.pdf, USDA: Animal and Plant Inspection Service, http://www.aphis.usda.gov/animal welfare/efoia/downloads/2009 Animals Used In Research.pdf

USDA (2011b) Livestock and poultry: World markets and trade. http://www.fas.usda.gov/psdonline/circulars/livestock poultry.pdf , USDA: Foreign Agricultural Service, http://www.fas.usda.gov/psdonline/circulars/livestock poultry.pdf

USGPO (1995) The Downed Animal Protection Act; Humane Methods of Poultry Slaughter Act; the Meat and Poultry Products Inspection Amendments of 1993: hearing before the Subcommittee on Livestock of the Committee on Agriculture, House of Representatives, One Hundred Third Congress, second session, on H.R. 559, H.R. 649, H.R. 3646, September 28, 1994. U.S. G.P.O., Washington

Utrecht U (2010) EXPERT MEETING: fish welfare: the interplay between science and ethics, Utrecht University.

http://www.uu.nl/faculty/humanities/EN/research/researchinstitutes/zeno/current/Pages/20101129fish-welfare.aspx

de Veer MW, Jr GGG, Theall LA, van den Bos R, Povinelli DJ (2003) An 8-year longitudinal study of mirror self-recognition in chimpanzees (pan troglodytes). Neuropsychologia 41(2):229-234. doi: 10.1016/S0028-3932(02)00153-7

de Waal FBM, Dindo M, Freeman CA, Hall MJ (2005) The monkey in the mirror: hardly a stranger. Proc Natl Acad Sci USA 102(32):11140-11147. doi:10.1073/pnas.0503935102, URL http://www.pnas.org/content/102/32/11140.abstract, http://www.pnas.org/content/102/32/11140.full.pdf?html

Wallace DF (2004) Consider the lobster. Gourmet

Walraven V, van Elsacker L, Verheyen R (1995) Reactions of a group of pygmy chimpanzees (Pan paniscus) to their mirror-images: evidence of self-recognition. Primates 36:145-150. doi:10.1007/BF02381922

Walters E, Illich P, Weeks J, Lewin M (2001) Defensive responses of larval manduca sexta and theirsensitization by noxious stimuli in the laboratory and field. J Exp Biol 204(3):457-469. URL 
http://jeb.biologists.org/content/204/3/457.abstract, http://jeb.biologists.org/content/204/3/457.full.pdf?html

Wellman HM, Cross D, Watson J (2001) Meta-analysis of theory-of-mind development: the truth about false belief. Child Dev 72(3):655-684. URL http://www.jstor.org/stable/1132444

White TI (2007) In defense of dolphins: the new moral frontier. Blackwell Pub., Malden, MA. URL http://www.loc.gov/catdir/toc/ecip0715/2007014522.html

Wigglesworth $\vee(1980)$ Do insects feel pain? Antenna 1:8-9

Wimmer H, Perner J (1983) Beliefs about beliefs: representation and constraining function of wrong beliefs in young children's understanding of deception. Cognition 13(1):103-128. doi:10.1016/00100277(83)90004-5

Wise SM (2002) Drawing the line: science and the case for animal rights. Perseus Books, Cambridge, MA. URL http://www.loc.gov/catdir/enhancements/fy0831/2002102642-d.html

Wollesen T, Loesel R, Wanninger A (2009) Pygmy squids and giant brains: mapping the complex cephalopod cns by phalloidin staining of vibratome sections and whole-mount preparations. J Neurosci Methods 179(1):63-67. doi:10.1016/j.jneumeth.2009.01.021

Wright AJ, Soto NA, Baldwin AL, Bateson M, Beale CM, Clark C, Deak T, Edwards EF, Fernández A, Godinho A, Hatch LT, Kakuschke A, Lusseau D, Martineau D, Romero ML, Weilgart LS, Wintle BA, Notarbartolo-di Sciara G, Martin V (2007) Anthropogenic noise as a stressor in animals: a multidisciplinary perspective. Int J Comp Psychol 20(2). URL http://www.escholarship.org/uc/item/46m4q10x

WSPA (2012) Sentience mosaic. website, URL http://www.animalmosaic.org/sentience/

Yue S, Moccia R, Duncan I (2004) Investigating fear in domestic rainbow trout, oncorhynchus mykiss, using an avoidance learning task. Appl Animal Behav Sci 87(3-4):343-354. doi:10.1016/j.applanim.2004.01.004, URL http://www.sciencedirect.com/science/article/pii/S0168159104000206 